\title{
Analisis Faktor - Faktor yang Mempengaruhi Kemiskinan (Studi Kasus di Kabupaten Banjarnegara, Cilacap, Purbalingga, Kebumen, dan Banyumas)
}

\author{
Hendry Wijaya ${ }^{1 *}$, Istiqomah ${ }^{2}$, Arintoko $^{3}$ \\ ${ }^{1,2,3}$ Fakultas Ekonomi dan Bisnis, Universitas Jenderal Soedirman \\ Jl. Prof. Dr. H.R. Boenyamin No.708, Kabupaten Banyumas, 53122 \\ *Coresponding: hendry_wijaya@live.com
}

\begin{abstract}
Abstrak. Penelitian bertujuan menganalisis pengaruh inflasi, PDRB dan IPM terhadap kemiskinan di Kabupaten Banjarnegara, Cilacap Purbalingga, Kebumen, dan Banyumas. Data yang digunakan dalam penelitian ini adalah data sekunder dalam rentang tahun 2000-2019. Metode yang digunakan adalah regresi linier berganda dengan pendekatan data panel. Output regresi dengan model fixed effect menunjukkan variabel inflasi tidak berpengaruh signifikan terhadap tingkat kemiskinan dan variabel PDRB dan IPM berpengaruh negatif signifikan terhadap tingkat kemiskinan di Kabupaten Banjarnegara, Cilacap Purbalingga, Kebumen, dan Banyumas. Temuan ini mengimplikasikan pemerintah daerah agar dapat menciptakan kesempatan kerja yang lebih banyak dan memberikan pelatihan serta meningkatkan infrastruktur pendidikan dan kesehatan.
\end{abstract}

Kata Kunci: Kemiskinan; Inflasi; Produk Domestik Regional Bruto; dan Indek Pembangunan Manusia

Abstract. This study aims to analyze the effect of inflation, Gross Regional Domestic Product, and Human Development Index on poverty in Banjarnegara, Cilacap Purbalingga, Kebumen, dan Banyumas Regencies. The data used in this study are secondary data in the period 2000-2019. With the multiple linear regression method panel data. The regression output with the fixed effect model shows that the inflation variable does not have a significant effect on poverty, and the Human Development Index and Gross Regional Domestic Product variables have a negative and significant effect on poverty in Banjarnegara, Cilacap Purbalingga, Kebumen, dan Banyumas Regencies. This finding implies local governments to create jobs and provide training and improve education infrastructure and health infrastructure.

Keywords: Poverty; Inflation; Gross Regional Domestic Product; and Human Development Index

\section{PENDAHULUAN}

Kemiskinan merupakan permasalahan hampir semua negara di dunia, terutama di negara berkembang. Kemiskinan memiliki sifat multidimensional yang mengandung arti manusia memiliki kebutuhan yang bermacam-macam. Maka dari kemiskinan dapat ditinjau dari aspek primer seperti miskin karena aset, ilmu pengetahuan, keterampilan dan aspek sekunder yaitu berupa miskin akan jaringan sosial, sumber-sumber keuangan, dan informasi (Arsyad, 2010).

Dampak kemiskinan sangatlah kompleks, orang miskin akan kesulitan memenuhi kebutuhan pangannya, sehingga akan berpengaruh pada tingkat kesehatan dan tingkat produktivitas. Dengan produktifitas yang rendah akan menyebabkan pendapatan yang rendah, dengan demikian orang miskin akan semakin kesulitan dalam memenuhi kebutuhan hidupnya (Jhingan, 2007). Jumlah penduduk miskin merupakan tujuan hal yang sangat penting untuk menilai berbagai efektifitas jenis program pembangunan.

Persentase kemiskinan yang cenderung menurun setiap tahun memperlihatkan bahwa penanggulangan kemiskinan di daerah Jawa Tengan berpengaruh positif. Namun, di Jawa Tengah masih memiliki persentase kemiskinan tinggi, yaitu dikawasan Karesidenan Banyumas yang meliputi Kabupaten Banjarnegara, Banyumas, Cilacap, Kebumen dan Purbalingga. Tabel 1 menunjukkan persentase kemiskinan di daerah tersebut dan Jawa Tengah.

Tabel 1. Persentase Kemiskinan Kabupaten Banjarnegara, Banyumas, Cilacap, Kebumen, Purbalingga dan Jawa Tengah Tahun 2011-2019 (Persentase)

\begin{tabular}{|c|c|c|c|c|c|c|c|c|c|c|}
\hline \multirow{2}{*}{ No } & \multirow{2}{*}{ Kabupaten } & \multicolumn{9}{|c|}{ Tahun } \\
\hline & & 2011 & 2012 & 2013 & 2014 & 2015 & 2016 & 2017 & 2018 & 2019 \\
\hline 1. & Banjarnegara & 20,38 & 18,87 & 18,71 & 17,77 & 18,37 & 17,46 & 17,21 & 15,46 & 14,76 \\
\hline 2. & Banyumas & 21,11 & 19,44 & 18,44 & 17,45 & 17,52 & 17,23 & 17,5 & 13,5 & 12,53 \\
\hline 3 & Cilacap & 17,15 & 15,92 & 15,24 & 14,21 & 14,39 & 14,12 & 13,94 & 11,25 & 10,73 \\
\hline 4 & Kebumen & 24,06 & 22,40 & 21,32 & 20,50 & 20,44 & 19.86 & 19,60 & 17,47 & 16,82 \\
\hline 5. & Purbalingga & 23,06 & 21,19 & 20,53 & 19,75 & 19,70 & 18,98 & 18,80 & 15,62 & 15,03 \\
\hline 6. & Jawa Tengah & 16,21 & 14,98 & 14,44 & 13,58 & 13,58 & 13,27 & 13,01 & 11,32 & 10,80 \\
\hline
\end{tabular}

Sumber: BPS Jawa Tengah tahun 2019 
Hendry Wijaya et al, Analisis Faktor - Faktor yang Mempengaruhi Kemiskinan (Studi Kasus di Kabupaten Banjarnegara, Cilacap, Purbalingga, Kebumen, dan Banyumas)

Untuk mengatasi kemiskinan di daerah tersebut, maka perlu diketahui faktor apa saja yang memengaruhi jumlah penduduk miskin di kabupaten-kabupaten tersebut, sehingga dapat digunakan sebagai bahan pertimbangan dalam merumuskan instrumen kebijakan dalam menangulangi jumlah penduduk miskin. Kelima kabupaten tersebut masuk dalam wilayah Karesidenan banyumas yang berada Bagian selatan provinsi Jawa Tengah yang mayoritas daerah berada di kawasan pesisir pantai selatan, yang mayoritas penduduknya bekerja di sektor pertanian. Faktor-faktor yang diduga memengaruhi tingkat kemiskinan di Kabupaten Banjarnegara, Cilacap Purbalingga, Kebumen, dan Banyumas seperti inflasi, pengangguran dan pengeluaran pemerintah.

Salah satu faktor yang menyebabkan terjadinya kemiskinan adalah tingginya tingkat inflasi yang menaikkan garis kemiskinan (Badan Pusat Statistik, 2013). Nopirin (2000) mengemukakan bahwa inflasi adalah kondisi dimana harga-harga barang dan jasa mengalami kenaikan yang terjadi secara terus menerus. Inflasi yang tinggi merupakan kecenderungan kenaikan harga barang dan jasa dimana tidak hanya terjadi pada satu jenis barang saja, tetapi meliputi barang-barang yang seringnya dikonsumsi oleh masyarakat yang juga dapat mempengaruhi harga barang lain.

Umumnya, tolok ukur dalam menentukan garis kemiskinan salah satunya bersumber dari harga barang dan jasa. Mankiw (2003) menjelaskan apabila laju inflasi terus mengalami kenaikan namun tidak diiringi dengan nilai mata uang riil yang menguat pada saatnya akan meningkatkan garis kemiskinan dimana jumlah penduduk miskin dapat meningkat jika tidak didukung dengan pendapatan masyarakat yang meningkat atau daya beli yang menguat. Hal ini disebabkan karena dengan naiknya harga barang dan jasa ini, maka nilai uang turun dan masyarakat terpaksa membayar sejumlah barang yang sama dengan harga yang lebih tinggi, sehingga pendapatan riil mereka turun (Kuncoro, 2009). Bagi kelompok dengan berpenghasilan rendah, inflasi akan membuat mereka mengurangi konsumsi atau mengganti barang konsumsi pada tingkatan yang lebih rendah. Secara riil uang yang dimiliki juga akan mengalami penurunan daya beli seiring dengan inflasi yang meningkat sehingga akan menyebabkan meningkatnya jumlah penduduk miskin. Temuan Imelia (2012) menemukan bahwa inflasi memiliki pengaruh positif terhadap kemiskinan yang artinya semakin tinggi tingkat inflasi maka juga akan meningkatkan jumlah penduduk miskin.

Produk Domestik Regional Bruto (PDRB) merupakan nilai keseluruhan dari barang dan jasa yang dihasilkan oleh suatu negara pada periode waktu tertentu. Jumlah PDRB adalah indikator untuk menghitung pertumbuhan ekonomi. Pertumbuhan ekonomi memberikan peluang bagi suatu wilayah untuk mengatasai berbagai masalah yang dihadapai salah satunya adalah kemiskinan. Hal ini dikarenakan cermin dari kesejahteraan suatu masyarakat dapat dilihat dari bagaimana perekonomian wilayah tersebut dapat tumbuh. Kuznets dalam Tambunan (2001) menyatakan bahwa pertumbuhan ekonomi dan kemiskinan memiliki keterkaitan yang kuat dimana dalam tahap awal pembangunan kemiskinan cenderung mengalami peningkatan karena alokasi penerimaan pendapatan ditujukan pada sektor-sektor yang mengutamakan pembangunan berskala besar. Namun pada akhir pembangunan jumlah penduduk miskin akan menurun secara berangsur-angsur.

Pertumbuhan ekonomi indikakor yang menunjukkan bahwa wilayah tersebut sedang berkembang dengan baik. Namun, sebaliknya apabila perekonomian tidak bertumbuh akan menyebabkan masalah ekonomi dan sosial. Tingkat kemiskinan dapat diturunkan apabila Produk Domestik Regional Bruto (PDRB) secara riil meningkat. Jundi (2004) juga mengatakan bahwa meningkatnya PDRB mencerminkan produktivitas yang meningkat yang menimbulkan pendapatan masyarakat juga dapat meningkat, sehingga jumlah penduduk miskin akan turun. Temuan Susanty (2013) dan Akhtar et al. (2013), menunjukan produk domestik regional bruto (PDRB) berkorelasi negatif terhadap angka kemiskinan.

Salah satu faktor yang mempengaruhi jumlah penduduk miskin adalah Indeks Pembangunan Manusia (IPM). Todaro (2000) mengatakan bahwa tujuan pembangunan itu sejatinya adalah pembangunan manusia. SDM yang berkualitas turut berkontribusi penting dalam upaya membangun perekonomian secara berkesinambungan. IPM memberikan gambaran mengenai pembangunan hidup yang layak dengan tiga komponen, yaitu kesehatan, pendidikan, kemampuan daya beli. Pembangunan manusia yang diukur melalui Meningkatnya IPM dapat menurunkan jumlah penduduk miskin (Suliswanto, 2010). Namun, rendahnya IPM akan menunjukkan rendahnya kualitas manusia yang dapat mengganggu produktivitas kerja. Produktivitas kerja yang rendah memberikan dampak pada pendapatan yang diperoleh, sehingga jumlah penduduk miskin akan bertambah. Temuan Susanty (2013) dan Pratama (2014) menemukan bahwa IPM berpengaruh negatif terhadap kemiskinan..

Dengan demikian penelitian bertujuan menganalisis pengaruh inflasi, Produk Domestik Regional Bruto, dan Indeks Pembangunan Manusia terhadap kemiskinan di Kabupaten Banjarnegara, Banyumas, Cilacap, Kebumen dan Purbalingga. 
Hendry Wijaya et al, Analisis Faktor - Faktor yang Mempengaruhi Kemiskinan (Studi Kasus di Kabupaten Banjarnegara, Cilacap, Purbalingga, Kebumen, dan Banyumas)

\section{METODE}

Metode dalam penelitian ini menggunakan regresi data panel. Data panel yaitu gabungan antara data time series dan cross section. Data yang digunakan menggunakan data sekunder berasal dari BPS. Obyek penelitian ini adalah tingkat kemiskinan, tingkat inflasi, PDRB dan IPM terhadap kemiskinan di Kabupaten Banjarnegara, Banyumas, Cilacap, Kebumen dan Purbalingga pada tahun 2000-2019. Berikut definisi dari variabel - variabel penelitian:

1. Kemiskinan merupakan persentase jumlah penduduk miskin yang penghasilanya di bawah garis kemiskinan di Kabupaten Banjarnegara, Banyumas, Cilacap, Kebumen dan Purbalingga (dalam satuan persentase).

2. Inflasi merupakan merupakan kecenderungan hargaharga barang dan jasa yang mengalami kenaikan secara terus-menerus di Kabupaten Banjarnegara, Banyumas, Cilacap, Kebumen dan Purbalingga (dalam satuan persentase).

3. Produk Domsetik Regional Bruto (PDRB) merupakan jumlah nilai barang dan jasa yang dihasilkan di suatu wilayah dalam suatu waktu (dalam satuan juta rupiah).

4. Indeks Pembangunan Manusia (IPM) merupakan indikator dalam menentukan kualitas pembangunan manusia.

Regresi linier berganda data panel adalah gabungan dari data time series dan cross section. Berikut adalah rumus persamaan penelitian:

$$
\begin{aligned}
& K E M_{i t}=\beta_{0}+\beta_{1} I N_{1 i t}+\beta_{2} P D R B_{2 i t}+\beta_{3} I P M+\varepsilon_{i t} \\
& \text { Keterangan : } \\
& \text { KEM = Kemiskinan (Persen) } \\
& \text { IN } \quad=\text { Inflasi (Persen) } \\
& \text { PDRB = Produk Domestik Regional Bruto (Juta } \\
& \text { Rupiah) } \\
& \text { IPM } \quad=\text { Indeks Pembangunan Manusia } \\
& \beta_{0} \quad=\text { konstanta } \\
& \beta_{1}, \beta_{2,} \beta_{3}=\text { koefisien regresi } \\
& \mathrm{t} \quad=\text { time series } \\
& \mathrm{i} \quad=\text { cross section } \\
& \varepsilon \quad=\text { error term }
\end{aligned}
$$

Dalam penelitian ini terdapat satuan dan besaran variabel independe, maka dibuat model logaritma natural. Logaritma natural bertujuan untuk menghindari heterokedastisitas dan dapat mengetahui koefisiesn yang menunjukkan elastisitas. Dari pertimbangan tersebut maka persamaan dalam penelitian ini menjadi seperti berikut:

$$
\operatorname{In} Y_{i t}=\beta_{0}+\beta_{1} \operatorname{InIN} N_{1 i t}+\beta_{2} \operatorname{InPDRB}+\beta_{3} \operatorname{InIP} M_{3 i t}+\varepsilon_{i t}
$$

Teknik estimasi model regresi data panel memiliki tiga teknik yang dapat digunakan yaitu dengan metode
OLS (Common Effect), model Fixed Effect, model Random Effect. Kemudian menggunakan teknik yang lebih baik, dilakukan dengan cara 1) Uji Chow, 2) Uji Lagrange Multiplier dan 3) Uji Hausman. Selain itu, penelitian regresi linier berganda harus bersifat Best Linier Unbiased Estimator (BLUE), sehingga harus lolos uji asumsi klasik yang meliputi: 1) Multikolinearitas, 2) Heteroskedastisitas, dan 3) Autokorelasi (Gujarati, 2012).

\section{HASIL DAN PEMBAHASAN}

Model penelitian ini mengunakan model fixed effet dan sudah dinyatakan lolos asumsi klasik. Dengan demikian penelitian ini dapat dijabarkan lebih lanjut mengenai pengaruh masing-masing variabel independen terhadap dependen. Berikut ini Tabel 2 yang menujukkan ringkasan output regresi yang digunakan dalam penelitian ini.

Tabel 2. Ringkasan Output Regresi Model Fixed Effect

\begin{tabular}{llllr}
\hline \multicolumn{1}{c}{ Variabel } & Koefisien & $\mathrm{T}_{\text {Statistik }}$ & & $\mathrm{t}_{\text {tabel }}$ \\
\hline Inflasi & $-0,0020$ & $-0,0597$ & $>$ & $-1,673$ \\
PDRB & $-0,9143$ & $-7,4835$ & $<$ & $-1,673$ \\
IPM & $-0,9835$ & $-1,9324$ & $<$ & $-1,673$ \\
\hline$R$ Square & $=0,672$ & & & \\
\hline
\end{tabular}

Nilai koefisien regresi inflasi adalah $-0,914$ hal ini memiliki makna bahwa inflasi berdampak negarif terhadap kemiskinan. Selain itu, nilai $t_{\text {statistik }}$ inflasi lebih kecil daripada $t_{\text {tabel }}$ ini megartikan bahwa pengaruh inflasi terhadap kemiskinan di Kabupaten Banjarnegara, Cilacap Purbalingga, Banyumas, dan Kebumen tidak signifikan. Temuan ini berbeda bertolak belakang dengan penelitian Barika (2013 dan Endrayani (2016) yang menyatakan bahwa inflasi memiliki pengaruh positif dan signifikan terhadap tingkat kemiskinan. Nopirin (2000) menjelaskan bahwa inflasi yaitu proses kenaikan harga-harga umum barang dan jasa secara terus menerus selama periode suatu waktu. Selain itu, menurut Gillani, Rehman, \& Gill (2009) suatu kenaikan inflasi dalam batas yang wajar, dapat meningkatkan kondisi kesejahteraan masyarakat secara umum atau mengurangi jumlah penduduk miskin melalui peningkatan produksi pada sektor riil.

Nilai koefisien regresi PDRB adalah $-0,9143$ hal ini memiliki makna bahwa PDRB berdampak negarif terhadap kemiskinan. Selain itu, nilai $t_{\text {statistik }}$ PDRB lebih besar daripada $t_{\text {tabel }}$ ini megartikan bahwa pengaruh PDRB teradap kemiskinan di Kabupaten Banjarnegara, Cilacap Purbalingga, Banyumas, dan Kebumen adalah signifikan. Secara empiris, penelitian ini sesuai dengan temuan Zamzami (2014), Wahyuningsih \& Zamzami (2014), dan Silastri (2017) yang menunjukkan bahwa PDRB memiliki pengaruh negatif dan signifikan terhadap kemiskinan. Pertumbuhan PDRB yang tinggi meningkatkan pendapatan atau pengeluaran penduduk miskin yang tadinya jauh di bawah garis kemiskinan 
Hendry Wijaya et al, Analisis Faktor - Faktor yang Mempengaruhi Kemiskinan (Studi Kasus di Kabupaten Banjarnegara, Cilacap, Purbalingga, Kebumen, dan Banyumas)

menjadi lebih mendekati garis kemiskinan. Pertumbuhan ekonomi yang tinggi dan berkelanjutan adalah suatu keharusan bagi keberlangsungan pembangunan ekonomi dan peningkatan kesejahteraan masyarakat di suatu daerah. Apabila pertumbuhan ekonomi tidak diimbangi dengan peningakatan kesempatan kerja yang banyak maka mengakibatkan ketimpangan dalam pembagian dari penambahan pendapatan (cateris paribus), dan selanjutnya akan menciptakan sebuah kondisi dimana pertumbuhan ekonomi dengan tingkat kemiskinan tinggi (Tambunan, 2001).

Pertumbuhan ekonomi adalah dalam menurunkan jumlah penduduk di setiap daerah atau wilayah. Apabila pertumbuhan ekonomi mengalami kenaikan pada masing-masing provinsi hal ini mengindikasikan bahwa kinerja pemerintah daerah mampu menaikan kesejahteraan masyarakatnya, sehingga menurunkan jumah penduduk miskin di wilayahnya (Rusdarti dan Sebayang, 2013). PDRB merupakan indikator pertumbuhan ekonomi suatu daerah. Semakin tinggi nilai PDRB suatu wilayah, maka semakin tinggi pula potensi dari penerimaan daerah tersebut

Nilai koefisien regresi IPM adalah $-0,9835$ hal ini memiliki makna bahwa PDRB berdampak negarif terhadap kemiskinan. Selain itu, nilai $\mathrm{t}_{\text {statistik }}$ IPM lebih besar daripada $t_{\text {tabel }}$ ini megartikan bahwa pengaruh IPM teradap kemiskinan di Kabupaten Banjarnegara, Cilacap Purbalingga, Banyumas, dan Kebumen adalah signifikan. Temuan penelitian ini sejalan dengan Suliswanto (2010), Pratama (2014) dan Yolanda, (2017) yang menemukan IPM memiliki pengaruh negatif dan signifikan terhadap tingkat jumlah penduduk miskin.

Teori pertumbuhan ekonomi baru menjelaskan bahwa pemerintah memiliki peranan penting dalam mengembangkan dan meningkatkan kualitas sumberdaya manusia (human capital). Peningkatan kualitas sumberdaya manusia dapat dilihat dengan meningkatnya ilmu pengetahuan dan keterampilan seseorang (Khobadakhshi, 2011). Peningkatan ilmu pengetahuan dan keterampilan akan berkorelsi positif terhadap tingkat produktivitas kerja seseorang, yang pada akhirnya akan mampu mengurangi jumlah penduduk miskin. Maka dari itu, semakin tinggi tingkat pendidikan masyarakat, maka semakin meningkat juga pengetahuan dan keterampilan. Dengan demikian, akan mampu meningkatkan produktivitas, pendapatan dan terlepas dari lingkaran kemiskinan (Sitepu dan Sinaga, 2007). Dengan demikian, pendidikan termasuk salah satu modal manusia untuk meningkatkan produktivitas dan pendapatan serta untuk meningkatkan kesejahteraan.

\section{SIMPULAN}

Kesimpulan dari penelitian ini adaah bahwa variabel inflasi tidak memiliki pengaruh signifikan terhadap tingkat kemiskinan dan PDRB dan IPM berpengaruh negatif signifikan terhadap tingkat kemiskinan di Kabupaten Banjarnegara, Banyumas, Cilacap, Kebumen dan Purbalingga. Hasil ini mengimplikasikan pemerintah Daerah Kabupaten Banjarnegara, Banyumas, Cilacap, Kebumen dan Purbalingga juga perlu meningkatkan pendapatan atau penerimaan masyarakat dan IPM yaitu dengan menciptakan kesempatan kerja dan memberikan kemudahan prosedur kepada para investor, memberikan pelatihan kerja kepada masyarakat serta meningkatkan infrastruktur pendidikan maupun kesehatan di wilayah Kabupaten Banjarnegara, Banyumas, Cilacap, Kebumen dan Purbalingga.

Membuat kebijakan terkait kemudahan prosedur investasi sehingga memudahkan investor menanam modal. Maka akan mendorong perekonomian daerah dan membuka lapangan pekerjaan. Kemudian memberikan berbagai pelatihan kerja kepada masyarakat dan menambah infrastruktur pendidikan serta kesehatan.

\section{DAFTAR PUSTAKA}

Akhtar, R., Liu, H., and Ali, A. (2017). Influencing Factors of Poverty in Pakistan: Time Series Analysis. International Journal of Economic and Financial Issues, 7(2): 215-222.

Arsyad, L. (2010). Dasar-Dasar Ekonomika Pembangunan. UPP STIM YKPN. Yogyakarta.

Badan Pusat Statistik (2000-2019). Provinsi Jawa Tengah dalam Angka tahun 2000-2019). Semarang

Barika, B. (2013). Pengaruh Pertumbuhan Ekonomi, Pengeluaran Pemerintah, Pengangguran dan Inflasi Terhadap Tingkat Kemiskinan di Provinsi se Sumatera. Jurnal Perencanaan Ekonomi dan Perencanaan Pembangunan. 5(1):27-36.

Endrayani, N. K. E., \& Dewi, M. H. U. (2016). Analisis Faktor-Faktor yang Mempengaruhi Tingkat Kemiskinan Kabupaten/Kota di Provinsi Bali. EJurnal Ekonomi dan Bisnis Universitas Udayana. 5(1): 63-88.

Gujarati, D. (2012). Basic Econometric. Erlangga. Jakarta.

Hussain, S., \& Malik, S. (2011). Inflation and Economic Growth: Evidence from Pakistan. International Journal of Economics and Finance. 3(5): 262-276.

Jhingan, M. L. (2007). Ekonomi Pembangunan dan Perencanaan, Rajawali Pers. Jakarta.

Khobadakhshi, A. (2011). Relationship between GDP and Human Development Indices in India. International Journal of Trade, Economics and Finance. 2(3):251-253.

Kuncoro, M. (2009). Ekonomi Pembangunan: Teori, Masalah dan Kebijakan. UPP STIM YKPN. Yogyakarta.

Mankiw, N. G. (2003). Teori Makro Ekonomi Terjemahan. Jakarta: PT. Gramedia Pustaka Utama 
Hendry Wijaya et al, Analisis Faktor - Faktor yang Mempengaruhi Kemiskinan (Studi Kasus di Kabupaten Banjarnegara, Cilacap, Purbalingga, Kebumen, dan Banyumas)

Nopirin, N. (2000). Pengantar Ilmu Ekonomi Mikro dan Makro. Yogyakarta: BPFE.

Pratama, Y. C. (2014). Analisis Faktor-Faktor yang Mempengaruhi Kemiskinan di Indonesia. Jurnal Bisnis dan Manajemen. 4(2):210-223.

Rusdarti, R. \& Sebayang, L. K. (2013). Faktor-Faktor yang Mempengaruhi Tingkat Kemiskinan di Provinsi Jawa Tengah. Jurnal Economia. 9(1):1-9.

Silastri, N. (2017). Pengaruh Jumlah Penduduk dan Pendapatan Domestik Regional Bruto (PDRB) Terhadap Kemiskinan di Kabupaten Kuantan Singingi. Jurnal Matematika Integratif. 9(1):1-18.

Sitepu, R K.; Sinaga, B M. (2007) The Impact Of Human Capital Investment On Economic Growth And Poverty In Indonesia: Computable General Equlibriu. Soca: Jurnal Sosial Ekonomi Pertanian, 7(2):1-14.

Sugema, I., Irawan, T., Adipurwanto, D., Holis, D., \& Bakhtiar, T. (2010) The Impact of Inflation on Rural Poverty in Indonesiaan Econometrics Approach. International Research Journal of Finance and Economics. 58(1):50-57.

Susanty, S (2013). Pengaruh Produk Domestik Regional Bruto, Pengangguran dan Indeks Pembangunan Manusia terhadap Kemiskinan di Jawa Barat dengan Menggunakan Analisis Data Panel. Jurnal Matematika Integratif, 9(1):1-18.

Suliswanto, M. S. W. (2010). Pengaruh Produk Domestik Bruto (PDB) dan Indeks Pembangunan Manusia (IPM) Terhadap Angka Kemiskinan di Indonesia. Jurnal Ekonomi Pembangunan. 8(2):357-366.

Tambunan, T. (2001). Perekonomian Indonesia: teori dan temuan empiris. Ghalia Indonesia

Todaro, M. P. 2000. Pembangunan Ekonomi di Dunia Ketiga. EdisiKetujuh, Terjemahan Haris Munandar. Jakarta: Penerbit Erlangga

Wahyuningsih, Y. E. \& Zamzami, Z. (2014). Analisis Pengaruh Produk Domestik Regional Bruto dan Jumlah Penduduk Terhadap Tingkat Kemiskinan di Kabupaten Nagan Raya. Jurnal Ekonomi dan Kebijakan Publik Indonesia. 1(1):39-47.

Yolanda, Y. (2017). Analysis of Factors Affecting Inflation and its Impact on Human Development Index and Poverty in Indonesia. European Research Studies Journal. 20(4):38-56. 